\title{
Lumber Potential of Tropical Species in a Mixed Plantation: Assessment at 50 Months
}

\author{
Amanda Arantes Junqueira ${ }^{1}$ \\ Glaycianne Christine Vieira dos Santos ${ }^{1}$ \\ Osmar de Freitas Neves Junior ${ }^{1}$ \\ Carlos Eduardo Silveira da Silva ${ }^{1}$ (D) \\ Djeison Cesar Batista ${ }^{2}$ (1) \\ Alexandre Monteiro de Carvalho ${ }^{3}$
}

${ }^{1}$ Universidade Federal Rural do Rio de Janeiro, Instituto de Florestas, Programa de Pós-Graduação em Ciências Ambientais e Florestais, Seropédica, RJ, Brasil.

${ }^{2}$ Universidade Federal do Espírito Santo (UFES), Centro de Ciências Agrárias e Engenharias, Departamento de Ciências Florestais e da Madeira, Jerônimo Monteiro, ES, Brasil.

${ }^{3}$ Universidade Federal Rural do Rio de Janeiro, Instituto de Florestas, Departamento de Produtos Florestais, Seropédica, RJ, Brasil.

\begin{abstract}
The use of tropical species in forest plantations is an alternative to supply the demand of good quality wood. However, information regarding the performance of planted tropical species is scarce. The aim of this study was to provide an assessment of the lumber potential of Cariniana legalis ("jequitibá-rosa”), Zeyheria tuberculosa ("ipê-felpudo") and Cordia trichotoma ("louro-pardo") in a forest plantation. Three trees per species were sampled at age of 50 months, planted in a mixed stand with $2 \times 4 \mathrm{~m}$ spacing in Porto Seguro, Bahia, Brazil. We assessed characteristics of the trees, the logs, lumber yield, and partial volumetric shrinkage of wood. Total volumetric shrinkage of ipê-felpudo, jequitibárosa and louro-pardo would be around $12.80 \%, 13.40 \%$ and $11.58 \%$, respectively. Among the three species analyzed, louro-pardo had the best performance, followed by ipê-felpudo, while jequitibá-rosa had the worst performance. All species had good performance regarding log quality and dimensional stability of wood.
\end{abstract}

Keywords: young trees, dendrometric characteristics, log quality, lumber yield.

\section{INTRODUCTION}

Tropical wood has traditionally been used in solid products due to its high quality. However, selective and continued exploration for these purposes have resulted in a scenario of threatened species (Costa et al., 2019; Lobão et al., 2010). According to Garcia et al. (2012), the Brazilian Amazon Forest has about six thousand species and logging is concentrated in only one hundred of them. This implies the search for viable alternatives to supply the demand for high quality wood in a sustainable way.

Brazilian law provides for the sustainable use of wood from native forests, in accordance with Law 12,651 of May 25, 2012 (Brazil, 2012), through an instrument called the Plan for Sustainable Forest Management (PSFM). However, obtaining the approval of a PSFM by the environmental agencies is time-consuming and and bureaucratic process, which can unviable a forest business regarding its economical aspect.

The use of tropical species in plantations has grown in the last two decades, and aims to supply good quality wood in a sustainable way (Fischer et al., 2015; Mendonça et al., 2018). One of the great advantages of these plantations is the simplified process of obtaining the harvest authorization, which dispenses the PSFM, as well as the better use of unproductive areas, often degraded and abandoned by agriculture.

However, there are few studies on the performance of tropical species in plantations, as well as on the quality of its wood. For example, Dias et al. (2012) evaluated the vegetative propagation of angico-vermelho progenies (Anadenanthera macrocarpa (Benth) Brenan); and Hernandez et al. (2013) evaluated the vegetative propagation of jequitibá-rosa (Cariniana estrellensis (Raddi) Kuntze). Other studies have 
evaluated tropical species in agroforestry systems (Radomski et al., 2012; Nicodemo et al., 2016) and in homogeneous plantations (Mendonça et al., 2017).

In the forest trade, the demand for wood from tropical forests has been showing an upward trend (Serviço Florestal Brasileiro e Instituto de Pesquisa Ambiental da Amazônia, 2011). These organizations estimated that the average demand for wood, in logs, from tropical forests is 21 million $\mathrm{m}^{3} /$ year, requiring an area of 36 million hectares in a 30-year cycle. Some authors also point out that there is an expectation regarding a decrease in the supply of tropical wood in Asian countries and in the Congo basin, which could highlight the Brazilian tropical wood market (Rodrigues et al., 2020).

Almeida et al. (2010) reinforce the idea of the potential for exporting tropical wood to the sawn wood market, aiming to replace commonly exported species. Silva et al. (2012) affirms that the tropical wood sector has great economic potential and already presents itself as an important income generator. The 2019 annual report (base year 2018) of the Agência Brasileira da Indústria de Madeira Processada Mecanicamente (ABIMCI), in 2018 Brazilian exports of hardwood sawnwood (including eucalyptus and other species) totaled 222 million dollars (556 thousand cubic meters of wood). According to the International Tropical Timber Organization (International Tropical Timber Organization, 2021), in December 2020 Brazilian exports of wood-based products (except pulp and paper) increased $47 \%$ in value compared to December 2019, with a value of 327.4 million dollars.

Tropical wood has a wide range of uses. Cariniana legalis (Mart.) Kuntze wood is indicated for light structures, ceilings, cladding, mouldings, furniture, decorative objects, packaging, and tool handles (Rolim et al., 2018). Cordia trichotoma wood has good workability and durability, and is indicated for furniture, sliced veneers, and turned parts (Zimmermann et al., 2017). Zeyheria tuberculosa wood is indicated for light structures, mouldings, furniture, decorative objects, and tool handles (Rolim et al., 2018).

The aim of this study was to provide a preliminary assessment of the lumber potential of three Brazilian tropical species in a forest plantation at age of 50 months.

\section{MATERIALS AND METHODS}

\subsection{Material collection and sampling area}

The material was collected in a mixed commercial plantation located in the city of Porto Seguro, Bahia, Brazil, with a climate classified as Af, according to the Köppen classification, and the soil classified as a yellow Latosol (Empresa Brasileira de
Pesquisa Agropecuária, 1999). Three trees were analyzed of each studied species, being them: Cariniana legalis (Mart.) Kuntze - "jequitibá-rosa”, Zeyheria tuberculosa (Vell.) Bureau ex Verl - "ipê-felpudo" and Cordia trichotoma (Vell.) Arráb. ex Steud - "louro-pardo", at age of 50 months, planted in spacing $2 \times 4 \mathrm{~m}$.

\subsection{Dendrometric characteristics}

For each tree, the diameter at breast height (DBH) was measured at $1.30 \mathrm{~m}$ from the soil. The total height and the commercial height were measured after the trees were harvested, and the latter was defined as the height equivalent to the diameter of $5 \mathrm{~cm}$. The diameters were also measured at every $1 \mathrm{~m}$ in length, from the base to the commercial height.

The volume of each section of $1 \mathrm{~m}$ was calculated using the Smalian method, obtaining the commercial volume (with bark) by the sum of the volume of each section. The form factor of the trees was calculated by the relationship between the commercial volume and the volume of a cylinder, calculated based on the DBH.

The bark percentage was calculated using only the first $\log (2 \mathrm{~m})$, according to the method of Imaña-Encinas et al. (2009), which considers the calculation of the diameter without bark.

\subsection{Log quality assessment}

To assess the quality of the logs, only the butt $\log (2 \mathrm{~m})$ was used. Flattening, taper and sweep were evaluated, based on the "Standard for measuring and classifying hardwood logs" (Instituto Brasileiro de Desenvolvimento Florestal, 1984). For flattening and taper, the diameters without bark were considered. Flattening was calculated by the ratio between the diameters of the small $(\mathrm{cm})$ and the large ends $(\mathrm{cm})$ of the $\log x 100 \%$. Sweep was calculated by the ratio between the sweep arrow $(\mathrm{cm})$ and the sweep length $(\mathrm{cm})$ of the $\log x 100 \%$. Taper was calculated based on Equation 1. All the characteristics were classified based on the criteria described in Table 1.

$\mathrm{T}=\frac{\frac{\left(\mathrm{d}_{1}+\mathrm{d}_{2}\right)}{2} \frac{\left(\mathrm{d}_{3}+\mathrm{d}_{4}\right)}{2}}{L .100}$

Where - $\mathrm{T}$ : taper (\%); $\mathrm{d} 1$ and $\mathrm{d} 2$ : diameters (without bark) perpendicular to each other at the large end $(\mathrm{cm}) ; \mathrm{d} 3$ and $\mathrm{d} 4$ : diameters (without bark) perpendicular to each other at the small end $(\mathrm{cm}) ; \mathrm{L}$ : total length $(\mathrm{m})$. 
Table 1. Classification criteria of logs.

\begin{tabular}{|c|c|c|c|c|c|c|c|c|}
\hline \multirow{2}{*}{ Characteristics } & \multicolumn{8}{|c|}{ Classes } \\
\hline & Superior & I & & II & & & & IV \\
\hline Flattening & $\geq 90 \%$ & $\geq 80 \%$ & & $\geq 70 \%$ & & & & \multirow{5}{*}{ n.s } \\
\hline Taper & $\leq 3 \%$ & $\leq 3 \%$ & & $\leq 4 \%$ & & & & \\
\hline \multirow{3}{*}{ Sweep } & $\mathrm{N}_{\mathrm{S}}=1$ & $\mathrm{~N}_{\mathrm{S}}=1$ & $\mathrm{~N}_{\mathrm{s}}=1$ & $\mathrm{~N}_{\mathrm{S}}=1$ & $\mathrm{~N}_{\mathrm{S}}=2$ & $\mathrm{~N}_{\mathrm{S}}=1$ & $\mathrm{~N}_{\mathrm{s}}=3$ & \\
\hline & $\mathrm{L}_{\mathrm{S}}=\mathrm{L}$ & $\mathrm{L}_{\mathrm{S}} \leq \mathrm{L} / 2$ & $\mathrm{~L}_{\mathrm{S}}=\mathrm{L}$ & $\mathrm{L}_{\mathrm{S}} \leq \mathrm{L} / 2$ & $\mathrm{~L}_{\mathrm{s}} \leq \mathrm{L} / 2$ & $\mathrm{~L}_{\mathrm{S}}=\mathrm{L}$ & $\mathrm{L}_{\mathrm{S}}=\mathrm{L}$ & \\
\hline & $\mathrm{E} \leq 5 \%$ & $E \leq 5 \%$ & $E \leq 5 \%$ & $\mathrm{E} \leq 8 \%$ & $\mathrm{E} \leq 5 \%$ & $\mathrm{E} \leq 8 \%$ & $\mathrm{E} \leq 5 \%$ & \\
\hline
\end{tabular}

Source: Instituto Brasileiro de Desenvolvimento Florestal (1984). n.s: not specified; Ns: number of sweeps; Ls: sweep length; L: log length.

\subsection{Log breakdown}

After evaluating the quality, the logs were processed using a portable sawmill (horizontal bandsaw), MCS Serrarias (Canoas, Brazil) model MCA-600, with a Honda GX 390 four-stroke gasoline engine rated at $13 \mathrm{HP}$, with $600 \mathrm{~mm}$ wheel diameter, equipped with a steel blade with width 45 $\mathrm{mm}$, spring-set teeth and kerf of $1.3 \mathrm{~mm}$. The live sawing pattern was adopted using manual advance at a feed speed of 1 meter per minute, valuing quality and safety. Then, the wood boards were edged to the largest width, using a circular saw equipped with a disc of $100 \mathrm{~mm}$ diameter disc, with tungsten carbide-inserted teeth and kerf of $3 \mathrm{~mm}$. The breakdown resulted in boards with $30 \mathrm{~mm}$ of thickness and width from 48 to $116 \mathrm{~mm}$ (according to the diameter of the logs).

The lumber yield was calculated with Equation 2, where $\mathrm{Y}$ is the yield (\%); $\mathrm{Vl}$ is the lumber volume $\left(\mathrm{m}^{3}\right)$ and $\mathrm{Vt}$ is the log volume, without bark $\left(\mathrm{m}^{3}\right)$.

$\mathrm{Y}=\frac{\mathrm{V} 1}{\mathrm{Vt}} \cdot 100$

The partial volumetric strinkage of wood was calculated considering the dimensions of the boards after breakdown (saturated condition) and after natural drying for 120 days, when the mean moisture content was $15 \pm 2 \%$.

\subsection{Statistical analysis}

The experiment was carried out in a completely randomized design (DIC), and three treatments (species) were assessed. The level of significance adopted was 5\% for all tests and statistical analysis was performed using the $\mathrm{R}$ software.

To analyze the effect of species on the analyzed properties, Analysis of Variance (ANOVA) was used, verifying the assumptions of normality and homoscedasticity, respectively with the tests of Shapiro-Wilk and Bartlett. When at least one of the assumptions was not met, data transformation was performed, considering the method of Box \& Cox (1964). In cases where the null hypothesis was rejected, the Scott-Knott means comparison test was applied.

\section{RESULTS AND DISCUSSION}

\subsection{Dendrometric characteristics}

The only dendrometric variable that did not meet the assumptions for performing ANOVA was the bark percentage, which did not have homocedastic variance $(\mathrm{M} / \mathrm{C}=7.07 ; \mathrm{P}$-value $=0.02)$, implying data transformation. The results of the dendrometric characteristics are shown in Table 2.

Table 2. Results of the dendrometric characteristics per species.

\begin{tabular}{|c|c|c|c|c|c|c|}
\hline Species & $\begin{array}{l}\text { Total Height } \\
\text { (m) }\end{array}$ & $\begin{array}{c}\text { Commercial } \\
\text { Height } \\
(\mathbf{m})\end{array}$ & $\begin{array}{l}\mathrm{DBH} \\
(\mathrm{cm})\end{array}$ & $\begin{array}{c}\text { Commercial } \\
\text { Volume } \\
\left(\mathrm{m}^{3}\right)\end{array}$ & $\begin{array}{l}\text { Form } \\
\text { Factor }\end{array}$ & $\begin{array}{c}\text { Percentage of } \\
\text { Bark (\%) }\end{array}$ \\
\hline Ipê-felpudo & $9.45^{\mathrm{a}}{ }_{(2.51)}$ & $5.5_{(6.30)}$ & $13.08^{\mathrm{a}}{ }_{(3.58)}$ & $0.0548_{(17.22)}^{\mathrm{a}}$ & $0.74_{(6.30)}$ & $14.91^{\mathrm{a}}{ }_{(0.52)}$ \\
\hline Jequitibá-rosa & $7.49^{\mathrm{b}}(4.11)$ & $3.5_{(24.74)}$ & $10.58_{(2.63)}^{\mathrm{b}}$ & $0.0252^{\mathrm{b}}{ }_{(11.30)}$ & $0.84_{(11.11)}$ & $11.18_{(10.00)}^{\mathrm{b}}$ \\
\hline Louro-pardo & $9.31_{(8.38)}^{\mathrm{a}}$ & $4.35_{(22.34)}$ & $12.14_{(6.43)}^{\mathrm{a}}$ & $0.0427^{\mathrm{a}}$ & $0.81_{(6.53)}$ & $7.53^{\mathrm{c}}{ }_{(17.16)}$ \\
\hline Shapiro-Wilk test (P-value) & $0.6801^{\mathrm{ns}}$ & $0.8418^{\text {ns }}$ & $0.8737^{\mathrm{ns}}$ & $0.9508^{\text {ns }}$ & $0.2585^{\mathrm{ns}}$ & $0.6888^{\mathrm{ns}}$ \\
\hline Bartlett test (P-value) & $0.2685^{\mathrm{ns}}$ & $0.4565^{\text {ns }}$ & $0.4484^{\mathrm{ns}}$ & $0.3745^{\text {ns }}$ & $0.6220^{\mathrm{ns}}$ & $0.1167^{\mathrm{ns}}$ \\
\hline F test (P-value) & $0.0054^{*}$ & $0.0529^{\text {ns }}$ & $0.00401^{*}$ & $0.00495^{*}$ & $0.2438^{\mathrm{ns}}$ & $2.0661 \mathrm{e}^{-05 *}$ \\
\hline
\end{tabular}

Means followed by the same letter in a column do not differ significantly (Scott-Knott test, $p>0.05$ ); coefficient of variation (\%) in parentheses; ${ }^{*}$ : significant at $5 \%$

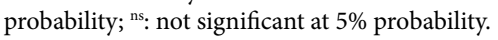


The statistical decision of the Scott-Knott test divided the means of total height, DBH and commercial volume into two groups of species, always with the same pattern: ipê-felpudo and louro-pardo, with the highest means values (not different from each other), and jequitibá-rosa with the lowest means values. These results previously indicates lower productive potential of the jequitibá-rosa species aiming at supplying the wood industry.

A total height of $8.44 \mathrm{~m}$ was reported for ipê-felpudo in homogeneous plantation, with $2 \times 2 \mathrm{~m}$ spacing, at age of 84 months (Mendonça et al., 2018). This result is practically $1 \mathrm{~m}$ shorter than that shown in Table 2 for ipê-felpudo $(9.45 \mathrm{~m})$ and indicates a future potential to obtain an even greater total height than reported in the literature, since the plantation is younger (50 months). On the other hand, means of $3.29 \mathrm{~m}$ and $3.94 \mathrm{~m}$ were reported for the same species, at a similar age (48 months), implanted in agrisilvicultural and silvopastoral systems, respectively (Nicodemo et al., 2016). These comparisons reinforce the good potential of material of ipê-felpudo of this study, as well as the advantage of planted forests for lumber production.

The louro-pardo species showed a total height value-also higher than that indicated in the literature, even for older plantations (60 months), in which means from $2.94 \mathrm{~m}$ to 4.37 $\mathrm{m}$ were reported in an agroforestry system (Radomski et al., 2012). In the same way as the previous comparison made for ipê-felpudo (Nicodemo et al., 2016), these results indicated the positive effect of planting in homogeneous spacing on the total height, when compared to other plantation systems that have greater spacing.

The commercial height was the only dendrometric variable in which there was no significant difference among species $(\mathrm{Fc}=4.989$; P-value $=0.0529)$, probably because of the high coefficients of variation of the species jequitibá-rosa and louro-pardo. However, as they are correlated measures, the absolute means of commercial height followed the same pattern as the total height, in which ipê-felpudo and jequitibárosa had the highest and lowest absolute means, respectively.

The means of DBH of ipê-felpudo and jequitibá-rosa were higher than those reported by Mendonça et al. (2017) for a plantation at age of 48 months, respectively $7.0 \mathrm{~cm}$ and $2.0 \mathrm{~cm}$. Just for ipê-felpudo, the mean DBH was also higher than that $(12.45 \mathrm{~cm})$ reported by Mendonça et al. (2018) for an older plantation ( 84 months) at $2 \times 2 \mathrm{~m}$ spacing. The mean DBH of louro-pardo was also higher than the range $(5.34 \mathrm{~cm}$ to $7.83 \mathrm{~cm})$ reported by Radomski et al. (2012) for a 60-month plantation in an agroforestry system. This information reinforces the indication of the studied material in comparison with results reported in the literature, and good adaptation to the soil and climate of the site.

Tree trunks have different shapes, from cylindrical to conical. The form factor is used to evaluate these formats, in which the closer to 1.00 , the more cylindrical the trunk is (Campos \& Leite, 2017). According to the results in Table 2 , there was no significant difference among the means of form factor of the species, and the results can be considered satisfactory, because they approached more to cylindrical logs, which are desirable for sawmills, as they produce smaller slabs, resulting in higher lumber yield.

The means of percentage of bark was significantly different among the species, with the highest and lowest means values for ipê-felpudo (14.91\%) and the louro-pardo (7.53\%), respectively. Despite its protective function on the trunk, the bark is not desirable for wood industrialization, requiring its removal in most processes. Exemplifying the sawmills processes, the bark transports extraneous materials that can damage the saws, as well as adheres to the equipment, impairing processing. Bark production also implies greater consumption of soil nutrients, impacting the costs of fertilizing future plantations. In a industrial view of the process, the important information is related to the productivity of high volume of biomass, expressed in Table 2 by the commercial volume, and low percentage of bark.

Eucalypt forests have the highest productivity $\left(35 \mathrm{~m}^{3} / \mathrm{ha} /\right.$ year) and the largest planted area in Brazil. This is the result of almost seven decades of research and development in the areas of forestry and breeding (Indústria Brasileira de Árvores, 2020). Due to the importance of eucalypt to Brazilian forestry and the low availability of articles on plantations of tropical species, it was considered valid to compare the total height and the DBH (Table 2) with those reported for eucalypt species.

For example, for eucalypt trees in an integrated-croplivestock-forest system (iCLF) at age of 51 months, a mean total height of $18.4 \mathrm{~m}$ was reported, that is, almost double than ipê-felpudo, which had the highest absolute mean $(9.45$ m) (Cerqueira et al., 2019). For trees of clonal material, an even higher mean was reported: $20.0 \mathrm{~m}$ (Vendruscolo et al., 2015). The DBH of the tropical species was comparable to that of clones of eucalypt hybrids ( 13.99 to $14.60 \mathrm{~cm}$ ), at age of 51 months (Cerqueira et al., 2019). For a plantation of similar age (48 months), the mean DBH was $13.7 \mathrm{~cm}$ and $14.3 \mathrm{~cm}$, respectively for clonal and seminal material (Vendruscolo et al., 2015). In this case, there was no such difference between the average DBH of eucalypt and ipê-felpudo or louro-pardo.

The greatest challenge for tropical species in terms of growth and productivity is more related to the apical meristem than to the vascular cambium meristem. This observation is important for the selection of parent trees for the collection of seeds, as well as for breeding these species. Yet, we suggest it is possible to obtain gains in productivity with the research and development of specific cultural and silvicultural treatments suitable for tropical species. 


\section{2. $\log$ Quality}

According to the results of Table 3, there was no significant difference among the species for all the analyzed log characteristics, which were used as quality criteria. Thus, the discussion was made only based on the classification criteria presented in Table 1 (Instituto Brasileiro de Desenvolvimento Florestal, 1984).

Table 3. Results of the log characteristics per species.

\begin{tabular}{|c|c|c|c|c|}
\hline \multirow{2}{*}{ Species } & \multicolumn{2}{|c|}{ Flattening (\%) } & \multirow{2}{*}{ Taper (\%) } & \multirow{2}{*}{ Sweep (\%) } \\
\hline & Large end & Small end & & \\
\hline Ipê-felpudo & $95.94_{(3.66)}$ & $92.22_{(6.05)}$ & $1.28_{(28.97)}$ & $1.19_{(67.38)}$ \\
\hline Jequitibá-rosa & $84.94_{(5.45)}$ & $87.26_{(18.04)}$ & $1.38_{(30.75)}$ & $2.93_{(87.43)}$ \\
\hline Louro-pardo & $88.65_{(13.70)}$ & $85.90_{(17.53)}$ & $1.36_{(42.66)}$ & $2.91_{(46.88)}$ \\
\hline Shapiro-Wilk test (P-value) & $0.7655^{\mathrm{ns}}$ & $0.1326^{\mathrm{ns}}$ & $0.4132^{\mathrm{ns}}$ & $0.2341^{\mathrm{ns}}$ \\
\hline Bartlett test (P-value) & $0.2573^{\mathrm{ns}}$ & $0.4382^{\text {ns }}$ & $0.8368^{\mathrm{ns}}$ & $0.3586^{\mathrm{ns}}$ \\
\hline $\mathrm{F}$ test (P-value) & $0.5158^{\mathrm{ns}}$ & $0.8266^{\mathrm{ns}}$ & $0.9615^{\text {ns }}$ & $0.4256^{\mathrm{ns}}$ \\
\hline
\end{tabular}

Coefficient of variation (\%) in parentheses; ns: not significant at $5 \%$ probability.

Flattening is measure of the circularity of the cross sections of the logs, where the closer to $100 \%$, more circular is the section. Circular sections are desirable, both for the ease of handling the logs during processing and for the indication of the quality of the wood. Flattened logs are associated with marrow eccentricity and tension wood (in the case of hardwoods) (Dias et al., 2017), which imply poorer wood quality, mainly for mechanical processing and drying. Ipê-felpudo was the only species with flattening classified as "superior" ( $\geq 90 \%)$, for both ends. Louro-pardo and jequitibá-rosa had worse results but; even so, the flattening of both species was classified in class I ( $\geq 80 \%$ ).

The taper of all species received the best classification ("superior", $\leq 3 \%$ ). Trees arranged in plantations, with homogeneous age and spacing compete for luminosity, inducing greater growth in height and less in diameter. This resulted in good form factor (Table 2) and low taper (Table 3), what are good characteristics for logs aimed to breakdown, because smaller slabs can be produced during the processing, resulting in higher lumber yeld.

The means of taper of the species are in the range reported by Carvalho et al. (2019) for Eucalyptus grandis (0.75 to 1.5\%), which is the most traditional species in Brazilian eucalypt culture. This indicates the good potential of the studied material, even in comparison with a breeded material.

According to the classification criteria adopted (Instituto Brasileiro de Desenvolvimento Florestal, 1984)., sweep below $2 \%$ should not be considered, such as that verified for ipê-felpudo. Jequitibá-rosa and louro-pardo, even with the presence of sweep, had their logs classified in the best class ("superior"). As with flattening, straight logs are easier to handle. Regarding wood processing, straighter logs are easier to adjust in the log carriage, as well as in any conveyor system (by chains, e.g.), in addition to resulting in higher lumber yield than logs with higher sweep.

\subsection{Lumber Yield and Volumetric Shrinkage}

According to the results in Table 4, there was a significant difference in the means of lumber yield among the species, in which louro-pardo had the highest mean value. Ipêfelpudo and jequitibá-rosa had lower yield and did not differ significantly from each other.

Table 4. Means of lumber yield and partial volumetric shrinkage per species.

\begin{tabular}{lcc}
\multicolumn{1}{c}{ Species } & Lumber yield (\%) & $\begin{array}{c}\text { Partial volumetric } \\
\text { shrinkage (\%) }\end{array}$ \\
\hline Ipê-felpudo & $35.64^{\mathrm{b}}{ }_{(16.22)}$ & $6.40_{(15.52)}$ \\
Jequitibá-rosa & $37.33^{\mathrm{b}}{ }_{(9.71)}$ & $6.70_{(39.42)}$ \\
\hline Louro-pardo & $53.53^{\mathrm{a}}{ }_{(6.70)}$ & $5.79_{(25.14)}$ \\
Shapiro-Wilk test (P-value) & $0.8256^{\mathrm{ns}}$ & $0.1339^{\mathrm{ns}}$ \\
\hline Bartlett test (P-value) & $0.7698^{\mathrm{ns}}$ & $0.09731^{\mathrm{ns}}$ \\
\hline F test (P-value) & $0.00481^{*}$ & $0.6038^{\mathrm{ns}}$ \\
\hline
\end{tabular}

Means followed by the same letter in a column do not differ significantly (Scottknott test, $\mathrm{p}>0.05$ ); results in parentheses indicate the coefficient of variation (\%).

In general, the lumber yield of hardwoods ranges from 45 to $55 \%$, which was verified only for louro-pardo. The lumber yield of ipê-felpudo and jequitibá-rosa was below $50 \%$, which may have occurred due to the small diameter of the logs (between 10.3 and $13.6 \mathrm{~cm}$ ), which has also been reported in the literature for Pinus spp. (35.79\%) between 16 to $23 \mathrm{~cm}$ (Serpe et al., 2018) and Eucalyptus grandis (48.6\%) between 20 to $27 \mathrm{~cm}$ (Anjos \& Fonte, 2017).

Higher lumber yields are verified in logs of larger diameter (Melo et al., 2016), due to the lower proportion of slabs and edgings in relation to the volume of logs, when compared to logs of smaller diameters. Although the mean diameter 
of louro-pardo logs $(12.1 \mathrm{~cm})$ did not differ significantly from ipê-felpudo $(13.1 \mathrm{~cm})$, the higher lumber yield can be explained by the lower percentage of bark of the former compared to the latter (Table 2).

There was no significant difference among species for the partial volumetric shrinkage, probably due to the high coefficients of variation ( $>15 \%$ for al species). This can be related to the variable dimensions of the boards, mainly the width. Louro-pardo had the lowest absolute mean (5.79\%).

The reported shrinkage (Table 4) refers to the partial shrinkage, from the saturated condition to approximately $15 \%$, exemplifying the mean moisture content of wood used in solid products. Considering that the shrinkage of wood from the fiber saturation point to $0 \%$ moisture content is practically linear (Galvão \& Jankowsky, 1985), it is inferred that we will obtain an estimate of the total shrinkage if we double the partial results. Thus, the total volumetric shrinkage of ipê-felpudo, jequitibá-rosa and louro-pardo would be around $12.80 \%, 13.40 \%$ and $11.58 \%$, respectively.

The Instituto de Pesquisas Tecnológicas of São Paulo (1989) reported total volumetric shrinkage of $12.9 \%$ for louro-pardo, that is, very close to what we estimated. This comparison indicates good quality of the louro-pardo wood from plantations evaluated in this study (juvenile wood), because the reference data (Instituto de Pesquisas Tecnológicas, 1989) refers to adult wood from trees from natural forests.

Rolim et al. (2018) reported means of volumetric shrinkage of ipê-felpudo (23 years), jequitibá-rosa (31 years), and louropardo (18 years) of $13.73 \%, 12.03 \%$ and $22.13 \%$, respectively. All of these results are close to the estimates reported in the present study. As juvenile wood has less dimensional stability (Dias et al., 2017), it was expected that the estimates would be comparatively worse than the results in the literature for older trees (Rolim et al., 2018), what did not occur, indicating the good quality of the material studied.

For Tectona grandis wood from a plantation of seven years, a total volumetric shrinkage of $8.1 \%$ was reported (Gil et al., 2018). Using the logic of doubling the partial shrinkage, we verified that the three species (Table 4 ) were more instable than Tectona grandis, which is considered a species of high dimensional stability.

Despite the high productivity, it is known that juvenile eucalypt wood has low dimensional stability. Following the the same pattern of comparison made previously, Talgatti et al. (2018) obtained a volumetric shrinkage of $12.93 \%$ for juvenile E. grandis $\mathrm{x}$ E. urophylla wood (72 months). Therefore, wood of the three tropical species (Table 4) is more dimensionally stable than eucalypt wood, reinforcing one of the initial premises of the study: seeking alternatives for the sustainable production of good quality wood to supply the wood industry.

\section{CONCLUSIONS}

Among the three species analyzed, louro-pardo had the best performance at age of 50 months, followed by ipê-felpudo, while jequitibá-rosa had the worst performance.

Considering the dendrometric characteristics, louropardo had the best performance, followed by ipê-felpudo. The tiebreaker criterion between these species was the lowest percentage of bark of louro-pardo.

The logs of the three species had a good quality classification (Superior and Class I) in terms of flattening, taper and sweep. However, based on the sweep criterion, ipê-felpudo had the best quality.

The wood of all species had good dimensional stability considering the partial volumetric shrinkage. Louro-pardo had the highest lumber yield, reinforcing its best performance to supply the wood industry.

It is suggested that these assessments be monitored as the stand grows older, including other assessments, such as wood density, heartwood: sapwood ratio and transition from juvenile to adult wood.

\section{ACKNOWLEDGEMENTS}

This study was financed in part by the Coordenação de Aperfeiçoamento de Pessoal de Nível Superior - Brasil (CAPES) - Finance Code 001. The authors thank them and Symbyosis Investimentos, for making available the study materials.

\section{SUBMISSION STATUS}

Received: 26 Feb. 2021

Accepted: 08 Jul. 2021

Associate editor: Fernando Gomes

\section{CORRESPONDENCE TO}

\section{Amanda Arantes Junqueira}

Universidade Federal Rural do Rio de Janeiro (UFRRJ), Instituto de Florestas, Programa de Pós-Graduação em Ciências Ambientais e Florestais, Rod. BR 465, Km 07, CEP 23890-000, Seropédica, RJ, Brasil e-mail: arantesaj@gmail.com

\section{REFERENCES}

Agência Brasileira da Indústria de Madeira Processada Mecanicamente (ABIMCI). Estudo Setorial 2019 (Ano base 2018). Curitiba: Gráfica e Editora Kaygangue; 2019.

Almeida NA, Angelo H, Silva JCGL, Hoeflich VA. Mercado de madeiras tropicais: substituição na demanda de exportação. Acta Amazonica 2010; 40(1): 119-126. https://doi.org/10.1590/S004459672010000100015

Anjos RAM, Fonte APN. Rendimento de madeira serrada de espécies de Eucalyptus. Revista de Ciências Agroveterinárias 2017; 16(1): 26-32. http://dx.doi.org/10.5965/223811711612017026 
Box GEP, Cox DR. An analysis of transformations. Journal of the Royal Society 1964; 26(1): 211-252. https://www.ime.usp.br/ abe/ lista/pdfQWaCMboK68

Brasil. Lei $\mathrm{n}^{\circ} 12.651$, de 25 de maio de 2012. Diário Oficial da República Federativa do Brasil, Brasília, DF (2012 maio 28). http:// www.planalto.gov.br/ccivil_03/_ato2011-2014/2012/lei/112651. htm\#: :text=1\%C2\%BA\%20(VETADO).-,Art.,n\%C2\%BA\%20 $571 \% 2 \mathrm{C} \% 20 \mathrm{de} \% 202012$ )

Campos JCC, Leite HG. Mensuração florestal: Perguntas e respostas. 5 a ed. Viçosa: Editora UFV; 2017.

Carvalho DE, Rocha MP, Klitzke RJ, Cademartori PHG. Eficiência operacional da serra de fita no desdobro de eucalipto. Tecno-Lógica 2019; 23(1), 36-41. http://dx.doi.org/10.17058/tecnolog.v23i1.12571

Cerqueira CL, Môra R, Tonini H, Vendruscolo DGS, Lanssanova LR et al. Efeito do espaçamento e arranjo de plantio na relação hipsométrica de eucalipto em sistema consorciado de produção. Nativa 2019; 7(6): 763-770. http://dx.doi.org/10.31413/nativa.v7i6.7643

Costa OB, Matricardi EAT, Pedlowski MA, Miguel EP, Gaspar RO. Selective logging detection in the Brazilian Amazon. Floresta e Ambiente 2019; 26(2): 1-10. https://doi.org/10.1590/2179-8087.063417

Dias ACC, Marchesan R, Pieroni GB, Almeida VC, Vieira RS et al. Qualidade da madeira para produção de lâminas de Araucaria angustifólia (Bert.) O. Kuntze. Floresta 2017; 47(3): 333-341. https:// doi.org/10.5380/rf.v47i1.50732

Dias PC, Xavier A, Oliveira LS, Paiva HN, Correia ACG. Propagação vegetativa de progênies de meios-irmãos de angicovermelho (Anadenanthera macrocarpa (Benth) Brenan) por miniestaquia. Revista Árvore 2012; 36(3): 389-399. https://doi. org/10.1590/S0100-67622012000300001

Empresa Brasileira de Pesquisa Agropecuária. Sistema brasileiro de classificação de solos. $1^{\text {a }}$ ed. Brasília: Embrapa; 1999.

Fischer A, Surdi AP, Junior SS, Winck CA. A Silvicultura Madeireira na Secretaria de Desenvolvimento Regional de Joaçaba-SDR de Joaçaba. Desenvolvimento em Questão 2015; 13(29): 225-256. https://doi.org/10.21527/2237-6453.2015.29.225-256

Galvão APM, Jankowsky IP. Secagem racional da madeira. $1^{\text {a }}$ ed. São Paulo: Nobel; 1985.

Garcia FM, Manfio DR, Sansígolo CA, Magalhães PAD. Rendimento no desdobro de toras de itaúba (Mezilaurus itauba) e tauari (Couratari guianensis) segundo a classificação da qualidade da tora. Revista Floresta e Ambiente 2012; 19(4): 468-474. http:// dx.doi.org/10.4322/floram.2012.059

Gil JLRA, Barboza FS, Coneglian A, Sette Jr, CR, Silva MFD, Moraes MDAD. Características físicas e anatômicas da madeira de Tectona grandis Lf aos 7 anos de idade. Revista de Ciências Agrárias 2018; 41(2): 261-270. http://dx.doi.org/10.19084/RCA17149

Hernandez W, Xavier A, Paiva HND, Wendling I. Propagação vegetativa do jequitibá-rosa (Cariniana estrellensis (Raddi) Kuntze) por estaquia. Revista Árvore 2013;37(5): 955-967. https://doi. org/10.1590/S0100-67622013000500018

Imaña Encinas J, Rezende AV, Imaña CR, Santana OA. Contribuição dendrométrica nos levantamentos fitossociológicos. $1^{\mathrm{a}} \mathrm{ed}$. Brasília: Universidade de Brasília; 2009.

Indústria Brasileira de Árvores. Relatório 2020. São Paulo: Indústria Brasileira de Árvores; 2020.

International Tropical Timber Organization (ITTO). Tropical Timber Market Report. ITTO TTM Report; 2021.

Instituto Brasileiro de Desenvolvimento Florestal. Norma para medição e classificação de toras de madeira de folhosas. Brasília: IBDF; 1984.
Instituto de Pesquisas Tecnológicas. Fichas de características das madeiras brasileiras. 2a ed. São Paulo: IPT; 1989.

Lobão MS, Chagas MP, Costa DDSP, Ferreira ATB, Sette Junior CR, Carvalho IL et al. Agrupamento de espécies florestais pela similaridade das características físico-anatômicas e usos da madeira. Cerne 2010; 16(1): 97-105.

Melo RR, Rocha MJ, Junior FR, Stangerlin DM. (2016) - Análise da influência do diâmetro no rendimento em madeira serrada de cambará (Qualea sp.). Pesquisa Florestal Brasileira 2016; 36(88): 393-398. https://doi.org/10.4336/2016.pfb.36.88.1151

Mendonça AR, Silva JC, Aozai TS, Silva ER, Santos JS, Binoti DHB et al. Estimação da altura total de árvores de ipê felpudo utilizando modelos de regressão e redes neurais. Revista Brasileira de Biometria 2018; 36(1): 128-139. https://doi.org/10.28951/rbb.v36i1.154

Mendonça GCD, Chichorro JF, Mendonça ARD, Guimarães LADOP. Avaliação silvicultural de dez espécies nativas da Mata Atlântica. Ciência Florestal 2017; 27(1): 277-290. https://doi. org/10.5902/1980509826466

Nicodemo MLF, Muller MD, Porfírio-da-Silva V, Carpanezzi AA, Pezzopane JRM, Barioni Júnior W. Desenvolvimento de espécies florestais nativas em dois sistemas agroflorestais. Revista Árvore 2016; 40(4): 639-648. https://doi.org/10.1590/0100-67622016000400007

Radomski MI, Porfírio-da-Silva V, Cardoso DJ. Louro-pardo (Cordia trichotoma (Vell.) Arrab. Ex Steud.) em sistemas agroflorestais. $1^{\text {a }}$ ed. Colombro: Embrapa Florestas; 2012 https://www.embrapa.br/ busca-de-publicacoes/-/publicacao/945612/louro-pardo-cordiatrichotoma-vell-arrab-ex-steud-em-sistemas-agroflorestais

Rodrigues MI, Souza NA, Joaquim MS, Lustosa Júnior IM, Pereira RS. Concessão florestal na Amazônia brasileira. Ciência Florestal 2020; 30(4): 1299-1308. https://doi.org/10.5902/1980509821658

Rolim SG, Piotto, D, Carvalho AM, Latorraca JVF, Souza, JS, Reis, $\mathrm{CA}$ et al. Crescimento e características de espécies arbóreas em experimentos silviculturais no norte do Espirito Santo. In: Rolim SG, Piotto D. (Ed.) - Silvicultura e tecnologia de espécies da Mata Atlântica. Belo Horizonte: Rona; 2018.

Serpe EL, Figueiredo Filho A, Arce JE. Rendimento do desdobro de madeira em serraria convencional e diferentes simulações utilizando otimizador computacional. Biofix Scientific Journal 2018; 3(1): 103 108. https://doi.org/dx.doi.org/10.5380/biofix.v3i1.58058

Serviço Florestal Brasileiro e Instituto de Pesquisa Ambiental da Amazônia. Florestas Nativas de Produção Brasileiras Brasília, SFB; 2011.

Silva LF, Silva ML, Cordeiro SA. Análise do mercado mundial de madeiras tropicais. Revista de Política Agrícola 2012; 3(7): 48-54.

Talgatti M, Silveira AG, Santini EJ, Gorski L, Baldin T et al. Propriedades físicas e mecânicas da madeira de clones de eucalipto. Scientia Agraria Paranaensis 2018; 17(4): 434-442. https:// doi.org/10.18188/sap.v17i4.20294

Vendruscolo DGS, Drescher R, Souza HS, Moura JPVM, Mamoré FMD, Siqueira TDS. Estimativa da altura de eucalipto por meio de regressão não linear e redes neurais artificiais. Revista Brasileira de Biometria 2015; 33(4): 556-569. https://doi.org/10.13140/RG.2.1.1742.5684

Zimmermann APL, Tabaldi LA, Fleig FD, Michelon IJ, Marangon GP. Métodos de transplantio para utilização de mudas de regeneração natural de Cordia trichotoma. Revista Brasileira de Ciências Agrárias 2017; 12(1): 74-78. https://doi.org/10.5039/agraria.v12ila5416 